\title{
広範囲小腸切除の大腸運動機能におよぼす影響
}

\author{
弘前大学医学部 大内外科教室 \\ (主任 大内清太教授) \\ 小野慶一渡辺襄鈴木 行三士田博 \\ 阿保優杉山 譲 野崎 修一杉沢利雄

\section{INFLUENCE OF EXTENSIVE RESECTION OF THE SMALL INTESTINE ON THE MOVEMENT OF THE LARGE BOWEL}

\author{
Keiichi Ono, Noboru Watanabe, Kozo Suzuki, Hiroshi Tsuchida, Masaru Abo, \\ Yuzuru Sugryama, Shuichi Nozaki and Toshio Sugisawa
}

Department of Surgery, Hirosaki University Faculty of Medicine', Hirosaki

(Director: Prof. K. Oh-Uti)

An electromyographic study of the influence of extensive resection of the small intestine on the movement of the large bowels was carried out. Thirty mongrel dogs weighing 4 to $8 \mathrm{~kg}$ were used for experiments.

After one-third resection of the upper, middle or lower small intestine, electrical activity of the ascending colon was markedly repressed, while that of the descending colon was not so influenced.

The action potentials of the ascending colon almost disappeared after two-thirds resection of the upper, middle or lower small intestine, but the descending colon was not influenced by these procedures.

From the results mentioned above, it is considered that the function of the remaining small intestine after extensive resection was partially compensated by the ascending colon.

外科臨床では，広範囲小腸切除を心要とする場合は稀 ではなく，てれに関する研究はてれまで数多くなされて いる. しかし切除後の遺残腸管, 特に大腸の運動病態生 理については近藤 ${ }^{1,2)}$, 山本 $\left.{ }^{3}\right)$ の報告のほか, あまりみ あたらず，特に電気生理学的方面からの検討は全くなさ れていない.

そこでわれわれは広範囲小腸切除後の大腸運動機能の 病態生理について電気生理学的に検討をくわえた。すな
わち小腸の上 $1 / 3$ 切除, 中 $1 / 3$ 切除, 下 $1 / 3$ 切除および 上 $2 / 3$ 切除, 中 $2 / 3$ 切除, 下 $2 / 3$ 切除の 6 群の広範囲切 除犬をつくり，1 ケ月後の左側結腸および右側結腸の運 動機能はいかなる状態にあるものか, 竻電図学的観察を 行なったまたた消化管平滑筋の収縮蠕動を促進するとい われるセロトニンの血中および腸管組織内分布の変動を 測定し, 広範囲小腸切除との関係をあわせ検討した。 そ の結果, $2 \cdot 3$ の知見を得たのでてとに報告する.

\section{I. 実験材料および方法}

実験動物は体重 $10 \mathrm{~kg}$ 前後の成犬 30 頭を用い, 24 時 間絶食後，ラボナール 静脈麻酔下に正中切開にて 開腹 し，まず教室常用の径 $300 \mu$ の銀-塩化銀双極電極を極間 距離 $3 \mathrm{~mm}$ で右側結腸，左側結腸に漿膜側より刺入，縫 着固定して，それぞれの部位の活動電位を時定数 0.03 秒の増巾器を介してペンレコーダーにて記録観察した。

その後小腸の空腸起始部から回腸末端部までの長さを
計測し, 上, 中, 下の 3 部に等分し (図 1〜6), 切除予 定の小腸間膜静脈よりセロトニン 測定に必要な血液を $10 \mathrm{ml}$ 採血した後, 上 $1 / 3$, 中 $1 / 3$, 下 $1 / 3$, 上 $2 / 3$, 中 $2 / 3$ および下 $2 / 3$ の夫々の部分を切除し， 2 層にて端々 吻合を行ない閉腹した. 各群とも 5 頭ずつの切除犬をつ くり，1ケ月後再開腹して右側結腸, 左側結腸の漿膜側 から初回と同様の方法で 活動電位を 導出し 比較観察し 


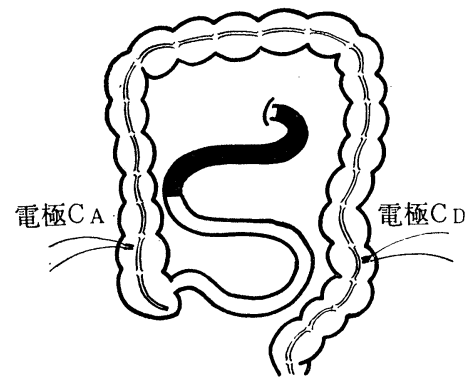

図 1. 小腸上部 $1 / 3$ 切除

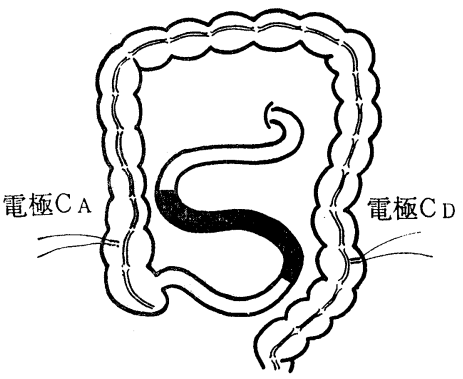

因 2. 小腸中部 $1 / 3$ 切除

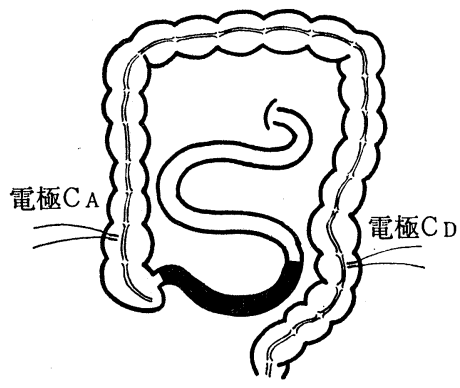

図 3. 小腸下部 $1 / 3$ 切除

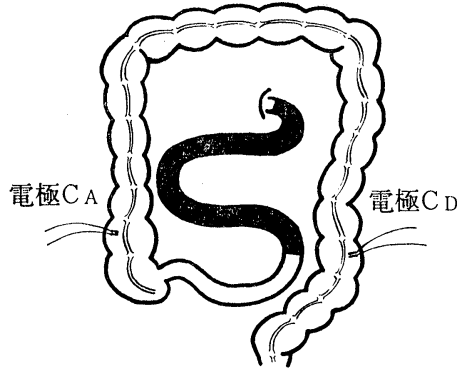

図 4 . 小腸上部 $2 / 3$ 切除

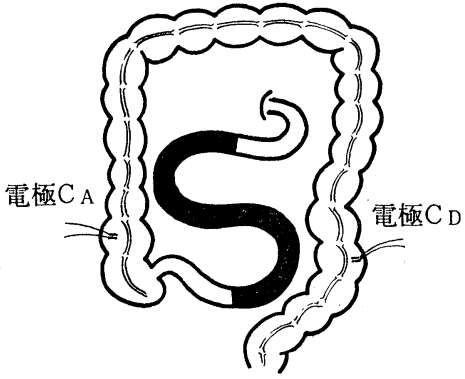

因 5 . 小腸中部 $2 / 3$ 切除

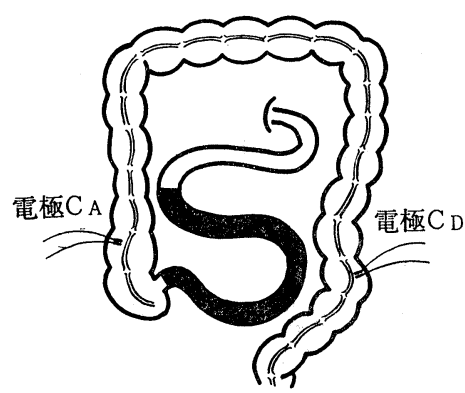

図 6. 小腸下部 $2 / 3$ 切除
た。さらに門脈血を採血した後，イヌを屠殺し小腸およ び大腸組織内のセロトニンを測定した。セロトニンの測
定法は Ashcroft と Crawford (1964) $\left.{ }^{4}\right)$ の方法にした がい, Faurand fluorophotometer で測定した。

\section{II. 実 験 成 績}

小腸非切除犬の右側結腸 および 左側結腸の活動電位 は, 図7 に示すごとく, 右側結腸では数コの spike 放 電が burst を形成して規則正しく出現し，左側結腸で

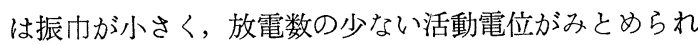
た。

図 8 は小腸の上 $1 / 3$ 切除犬の 1 ケ月後の右側結腸およ び左側結腸の活動電位で, 右側結腸においては非切除犬 のそれにくらべ同部の放電数の著明な減少がみられた。 また左側結腸では振巾が小さく放電数の規則性が失なわ れるようになった。
小腸の中 $1 / 3$ 切除犬では右側結腸, 左側結腸ともに規 則性のある burst 形成がみとめられず，特に右側結腸 では放電振巾がかさくなるように思われた。また左側結 腸は上 $1 / 3$ 切除犬と同様不規則な活動電位が出現するに すぎなかった（図 9 ).

小腸の下 $1 / 3$ 切除犬でも前 2 者と同様, 非切除犬にみ られた放電活動の規則性は失なわれた（図 10）.

つぎに小腸の上 $2 / 3$ を切除すると，右側結腸の活動電 位は $1 / 3$ 切除の場合よりもさらに不活発となって抑制さ れるが，左側結腸では非切除と同様に規則正しい活動電 


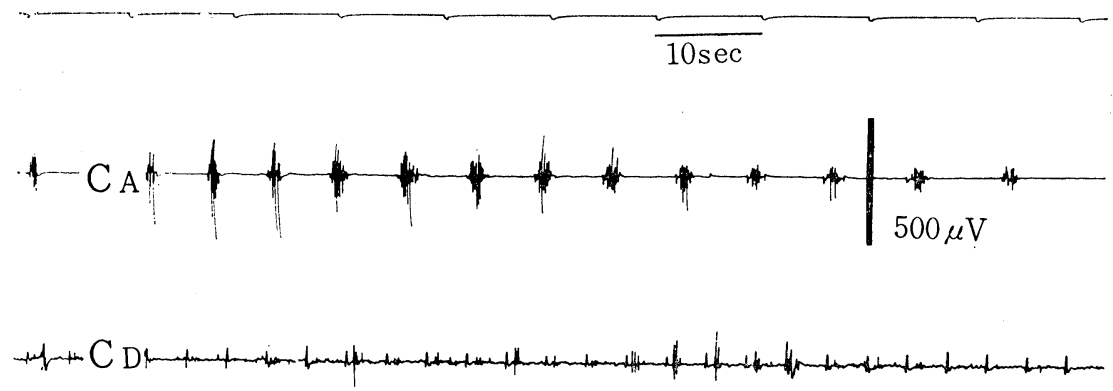

図 7. イヌの右側結腸 $\left(\mathrm{C}_{\mathrm{A}}\right)$, 左側結腸 $\left(\mathrm{C}_{\mathrm{D}}\right)$ の活動電位（非切除犬）

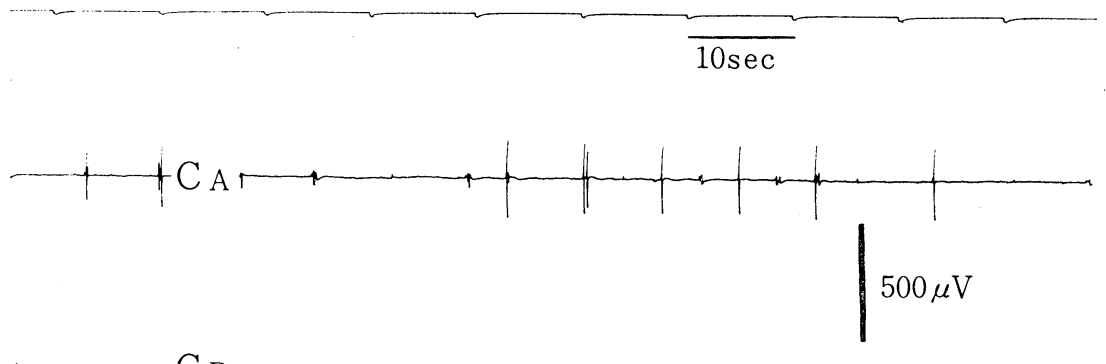

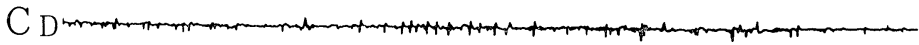

図 8. 小腸の上 $1 / 3$ 切除大の右側結腸 $\left(\mathrm{C}_{\mathrm{A}}\right)$, 左側結腸 $\left(\mathrm{C}_{\mathrm{D}}\right)$ の活動電位

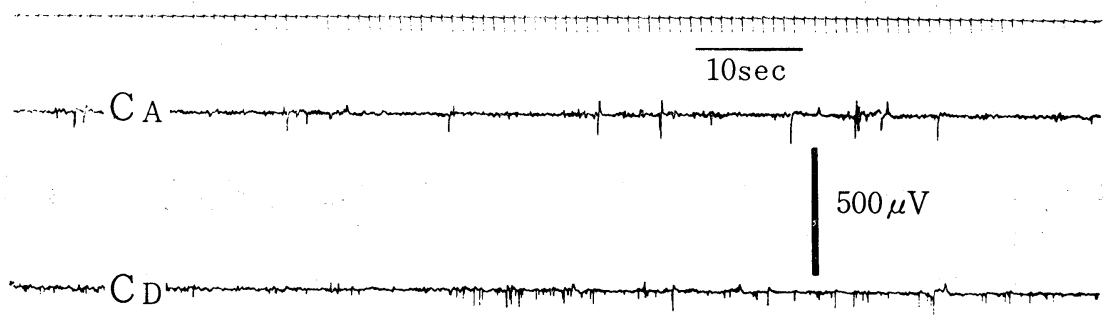

図 9 . 小腸の中 $1 / 3$ 切除大の右側結腸 $\left(\mathrm{C}_{\mathrm{A}}\right)$, 左側結腸 $\left(\mathrm{C}_{\mathrm{D}}\right)$ の活動電位

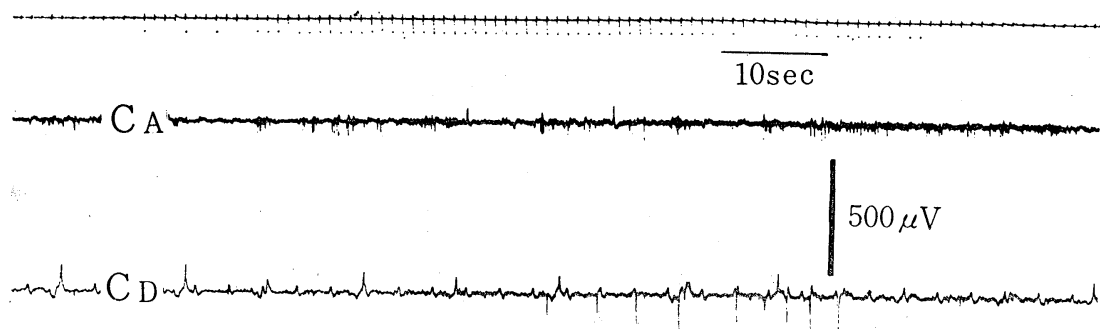

図 10. 小腸の下 $1 / 3$ 切除犬の右側結腸 $\left(\mathrm{C}_{\mathrm{A}}\right)$, 左側結腸 $\left(\mathrm{C}_{\mathrm{D}}\right)$ の活動電位

位がみられた（図 11）。

中 $2 / 3$ を切除すると右側結腸にははとんど放電活動が 出現せず，てれに反し左側結腸には振巾の大きい不規則 な活動電位が出現するようになった（図 12）.

また下 $2 / 3$ 切除犬では中 $2 / 3$ 切除の場合と同様, 右側 結腸では活動電位が著しく抑制されほとんぞみとめられ
なくなった・けれども左側結腸ではあまり著明な変化は なく，広範囲小腸切除の影響はほとんどみとめられなか った（図 13).

つぎに，セロトニンを非切除， $1 / 3$ 切除， $2 / 3$ 切除犬 の血中，小腸ならびに大腸組織内で測定し比較すると， 表 1 のでとく，小腸の切除量が増加するにしたがい，大 


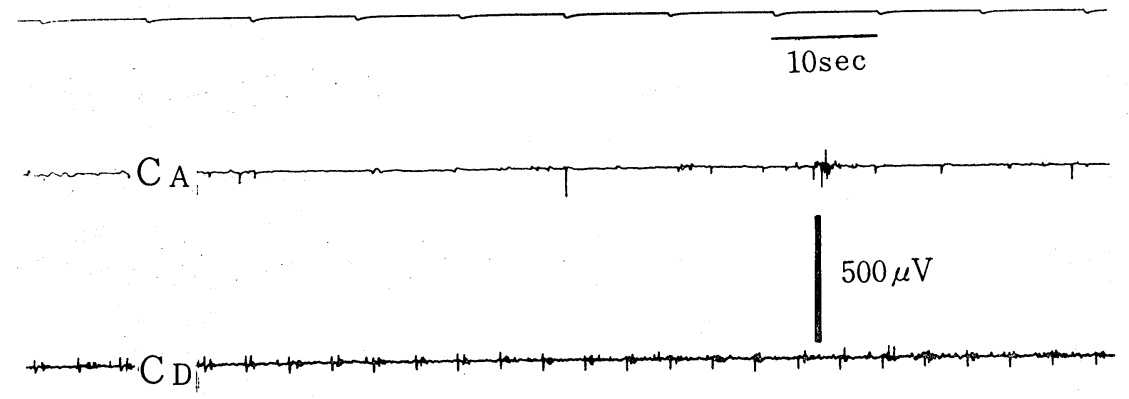

図 11. 小腸の上 $2 / 3$ 切除大の右側結腸 $\left(\mathrm{C}_{\mathrm{A}}\right)$, 左側結腸 $\left(\mathrm{C}_{\mathrm{D}}\right)$ の活動電位
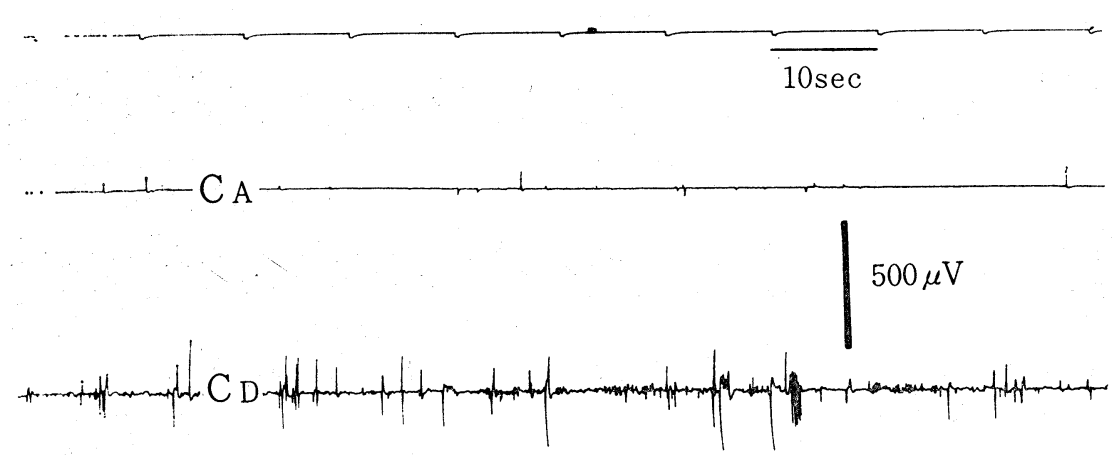

図 12. 小腸の中 $2 / 3$ 切除大の右側結腸 $\left(\mathrm{C}_{\mathrm{A}}\right)$, 左側結腸 $\left(\mathrm{C}_{\mathrm{D}}\right)$ の活動電位

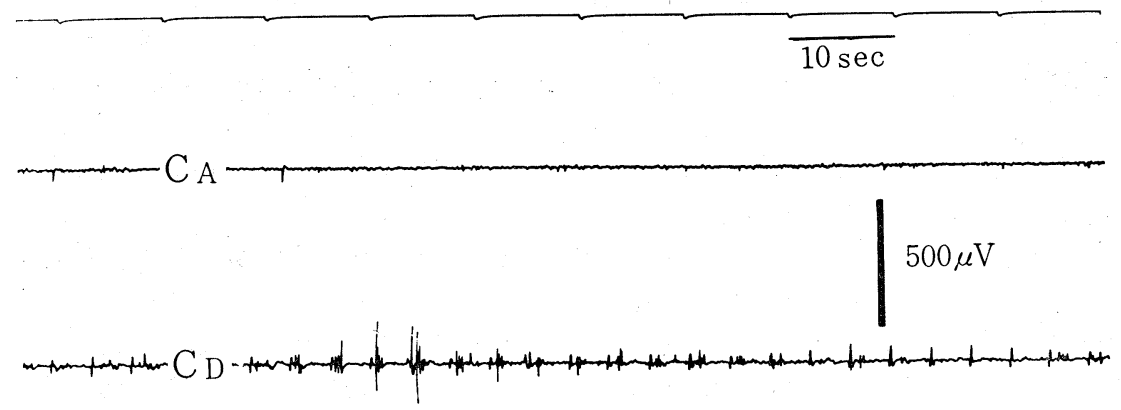

図 13. 小腸の下 $2 / 3$ 切除犬の右側結腸 $\left(\mathrm{C}_{\mathrm{A}}\right)$, 左側結腸 $\left(\mathrm{C}_{\mathrm{D}}\right)$ の活動電位

腸組織内セロトニンの量が減少する結果が得られた，し かし血中および小腸組織内セロトニンの量には有意の差 はみとめられなかった。
表 1. 広範囲小腸切除後のセロトニンの変動

\begin{tabular}{ll|r|r|r}
\hline & & 非切除 & $1 / 3$ 切除 & $2 / 3$ 切除 \\
\hline 血 中 & $(\gamma / \mathrm{ml})$ & 0.43 & 0.42 & 0.49 \\
小腸組織内 & $(\gamma / \mathrm{g})$ & 4.17 & 5.88 & 4.32 \\
大腸組織内 & $(\gamma / \mathrm{g})$ & 8.37 & 4.05 & 2.73
\end{tabular}

III. 総括ならびに考按

小腸と大腸は全く異なった運動をするといわれてい $3^{5-9)}$. 小腸では振子運動, 浅蠕動波, 蠕動および分節 運動の 4 つの運動型があるのに反し, 大腸では逆蠕動と 緊張性収縮輪との協力によって小腸から送られた腸内容
から水分吸収办行なわれるといわれている。てれら相異 なる運動を営む 2 つ腸管のどちらか一方が広範囲に切 除された場合, 生体防御反応の1つとして遺残腸管が他 の腸管の機能を代償しうるものかどうか興味のあるとて 
ろである。すなわち Monari は短縮された小腸の代償 的吸収を大腸が行なうと推論しているが，運動生理とく に電気生理の立場からてれを裏付ける報告はこれまであ まりみられなかった。

われわれは外科臨床上，やむを得ず広範囲に小腸を切 除する症例に遭遇するととは稀ではない，その際，術後 遺残腸管特に大腸機能にかかる手術的侵襲がいかなる影 響をもたらすものか，その病態生理についてはあまり立 入った検討が加えられていない. 最近, 消化吸収の面か らいわゆる医原性疾患としての吸収不良症候群がクロ一 ズアップされ，かかる立場から種々検討がなされるよう になったが，やはり運動生理の立場からはくわしく検討 がなされていないように思われる。

とてろで小腸のどの程度の範囲を切除した場合に広範 囲小腸切除といえるか，その定義についてはいまだ定説 を得ておらず，従来よりいろいろ議論のあるとてろであ る. しかし一般的にいって切除許容限界を $1 / 2 \sim 2 / 3$ と するものが多く, 近藤 ${ }^{1,2)}$ は小腸の切除部位に着目し, 消化吸收機能の面汃ら小腸切除の限界を上部汃 $2 / 3$, 下部から $3 / 4$ であるとし、上部からもまた下部からも $1 / 2$ 以上の切除をるって広範囲切除とよぶべきであると している.

われわれの実験もかかる見解を考慮にいれて，前述の ごとく 6 通りの切除群をつくった. その結果, $1 / 3$ 切除 犬では上・中・下の 3 群のいずれにおいても右側結腸の 放電活動が非切除犬のそれにくらべ著明に抑制され、ま た左側結腸においても放電群の規則性恃失われ，右側結 腸はどではないが一応の抑制効果がみとめられた．ての 事実は大腸とくに右側結腸での内容輸送の抑制化によっ て水分の有効な吸収を実現しようとする生体防御反応の 1つとも考えられる.すなわち小腸広範囲切除後におけ る大腸の機能的代償作用の 1 つとも考光られる.

$2 / 3$ 切除犬では, 上，中，下いずれの場合においても 右側結腸の放電活動は $1 / 3$ 切除犬の場合よりもさらに著 明に抑制されるようになる。乙のととは小腸の切除量が 多いはど右側結腸の運動が抑制され腸内容の輸送を遅延 させるという大腸の代償機序の一端を裏書きしているも

\section{IV. む}

広範囲小腸切除の大腸運動機能におよばす影響を解明 する目的で, 30 頭の成犬の小腸を上, 中, 下の 3 つの 切除部位にわけ，上 $1 / 3 \cdot$ 中 $1 / 3 \cdot$ 下 $1 / 3$ および 上 $2 / 3$ 中 $2 / 3$ ・下 $2 / 3$ 切除犬を作製し， 1 ケ月後の右側結腸お よび左側結腸の運動機能を電気生理学的に検討するとと もに，各切除群における血中，小腸ならびに大腸組織内 のセロトニンの変動を測定しつぎの結果を得た.

1. 上 $1 / 3$ 切除犬の右側結腸の活動電位では非切除犬
のと思われる.また $2 / 3$ 切除犬では左側結腸の活動電位 のパターンにはあまり影響はみとめられなかった。とく に下 $2 / 3$ 切除群では正常放電活動とあまり変らないパタ ーンを示していた.

小腸の $2 / 3$ 切除は 近藤 ${ }^{1,2)}$ ， 山本 ${ }^{3)}$ らものべているよ うに，いかゆる広範囲小腸切除の範疇に入るもの之考元 られる. そしてての際における右側結腸放電活動の著明 な抑制化傾向については，同部が発生学的に小腸と同じ 中腸という起源を有し，血管支配，神経支配もひとしく する点などから考えて, 機能代償の一種の表現と推定し 得よう。けれども左側結腸の抑制化傾向はあまり著明で ないという事実については，いかにてれを説明すべきか 問題のあるとてろである．近藤はイ又を用いての実験で かかる小腸の広範囲切除後においては，大腸でまず機能 的代償がおこなわれ，その後形態的代償があらわれると のべている，山本も同様，遺残腸管の代償作用をみとめ ている.

てれらの事実を考光あわせ，われわれの実験で得た大 腸活動電位の抑制化傾向はかかる機能的代償の 1 つのあ らわれとも考无られ興味深い。

セロトニンは 1933 年 Vialli と Erspamer が累暘管 粘膜の抽出物より分離して Enteramin と命名して以来, 各方面からの研究がなされ， tryptophan 誘導体である 5-hydroxytryptamine であるととが判った。 セロトニン はいろいろの薬理作用があるといわれ10,11), 循環系, 消化器系, 呼吸器系, 神経系化対するはたらきが最近知 られるようになった。とくに平滑筋に対しては胃腸管な ぞの収縮蠕動を促進し, 臨床的に疝痛, 下痢, 䓵吐など の症状を招来する。

最近, ダンピング症候群におけるセロトニンの意義が 注目されつつある12).

われわれの実験では，小腸を広範囲に切除すると血中 および小腸組織内のセロトニンは変化がみとめられない が, 大腸組織内セロトニンは減少し, 小腸の切除量が増 すに従い，セロトニンの減少が著しくなった．とのとと は右側結腸の運動抑制になんらかの関連を有するととが 推測され興味深い知見と考元られる。

\section{す ひ}

のそれにくらべ放電数の著明な減少がみられ，左側結腸 では振巾の小さい不規則な放電がみられた。

2. 中 $2 / 3$ 切除犬では右側結腸, 左側結腸ともに放電 活動は抑制され，非切除犬にみられた規則性は失われ た.とくに右側結腸では振巾が減少した。

3. 下 $1 / 3$ 切除犬でも前 2 者々同様, 非切除犬にみら れた放電活動の規則性は失なわれた。

4. 上 $2 / 3$ 切除犬の右側結腸の活動電位は $1 / 3$ 切除の 
場合よりもさらに著明に抑制されたけれども, 左側結腸 においては非切除犬とあまり変らず比較的規則正しい放 電活動が出現した。

5. 中 $2 / 3$ 切除犬では右側結腸にははとんど活動電位 がみられず，てれに反し左側結腸には振巾の大きい不規 則な活動電位が出現した。

6. 下 $2 / 3$ 切除犬の場合は中 $2 / 3$ 切除犬と同様, 右側 結腸には活動電位が全くみとめられず，左側結腸では非 切除犬とあまり変らない規則正しい放電活動がみられ

\section{文}

1) 近藤 悟 : 小腸広沉切除後の消化吸收機能に関 する研究 (その1). 日本外科学会雑誌, 61, 971 , 1960.

2) 近藤 悟 : 小腸広沉切除後の消化吸收機能に関 する研究 (その2), 日本外科学会雑誌, 61, 1126, 1960

3) 山本達郎：広沉小腸切除に関する実験的研究. 腸内容移動ならびに腸重量の変動. 日本外科学会 雑誌, 64, 645, 1563.

4) Ashcroft, G. W. \& Crawford, T. B. B. : Estimation of 5-hydroxytryptamine in human blood. Clinica chemica acta, 9, 364, 1964.

5) 福原 武：消化管運動の生理, 医学書院, 東京, 1953.

6）諬 哲夫，鈴木泰三：平滑筋筋電図の基礎と臨 床, 金原出版, 東京, 1966 .
た。

7. セロトニンの変動は血中および小腸組織内では有 意の差がなかったが，小腸の切除量が増すにしたがい， 大腸組織内七ロトニンの量は減少した。乙の事実は上述 の大腸放電活動の抑制化傾向になんらかの意義を有する ものと考觉られる.

本論文の要旨は昭和 41 年 7 月 21 日, 第 8 回日本平滑 筋学会総会において発表した.

献

7）福原 武： 壁内神経細胞による胃腸運動調節の 機序. 日平滑筋誌，3，1，1967

8）篠崎達世, 小見山喜八郎, 神 廉 : 小腸の $\mathrm{X}$ 線 診断. 総合臨床，14，1682，1965.

9) 植草 実 : 回盲部運動の病態生理, 外科診療, 9, $1,1967$.

10) 田坂定孝：臨床内分泌学, 中外医学社, 東京, 1961.

11）渋沢喜守雄, 斎藤純夫, 細谷貞一, 阿部栮郎： セロトニン，その外科的考察. 臨床外科，11， 795, 1956.

12) Thompson, T. J., Runcie, J. \& Miller, V. : 5-hydroxyindoles and kinins in the carcinoid and dumping syndromes. Lancet, 5, 986, 1966. 